\title{
French imperial politics and the long shadow of Francophonie
}

\begin{abstract}
The essay analyzes French language policy as a probe to set forth different notions of "cultural sovereignty" in France from the end of the $19^{\text {th }}$ century to decolonization. It traces the construction of Francophonie as a political project of the early $3^{\text {rd }}$ Republic that involved statal actors and institutions as well as scholarly and intellectual engagement and an emerging civil society. Although French language policy changed over the years and followed quite different ideas and practices in- and outside the Hexagon it aimed at control, cohesion and cultural sovereignty inside the French nation-state as well as in its colonies. In both cases the different target groups received and appropriated it in diverse and unintended ways. By analyzing the actors, ideas and practices of Francophonie as well as its internal and external facets in the same analytical field the essay tries to bring out the differences and commonalities of French notions of cultural sovereignty between metropole and empire.
\end{abstract}

“C'est avec 76.900 hommes que la France assure la paix et les bienfaits de sa civilisation à ses 60 millions d'indigènes." "This slogan praising the French colonial army adorned a well-known propaganda painting that was shown at the exposition coloniale in 1931. The exposition held in Paris during six months and attracting an estimated 8 million visitors is seen as the peak of French colonialism. After the allocation of the mandates by the League of Nations in the wake of the First World War the French colonial empire was larger than ever before but crises were looming everywhere. Against the background of nationalist and independence movements the exposition at the Porte Dorée and in the Parc de Vincennes was directed inwards as well as outwards and therefore also served to strengthen the self-assurance and identity of France as an influential colonial power. ${ }^{2}$

Accordingly, the painting does not only reproduce classical racist stereotypes towards indigenous people but also inscribes itself on the well-known

1 Transl.: "It is with 76,900 men that France ensures peace and the benefits of its civilization to its 60 million natives."

2 Charles-Robert Ageron, 'L’Exposition coloniale de 1931. Mythe républicaine ou mythe impérial?’, in: Pierre Nora (ed.), Les lieux de mémoire. Vol. 1, Paris 1984, 561-591; Catherine Hodeir/ Michel Pierre, L'Exposition coloniale, Paris 1931, Paris/Brussels 1991.

Ә Open Access. (C) 2021 Silke Mende, published by De Gruyter. (c) BY-NC-ND This work is licensed under the Creative Commons Attribution-NonCommercial-NoDerivatives 4.0 International License. 


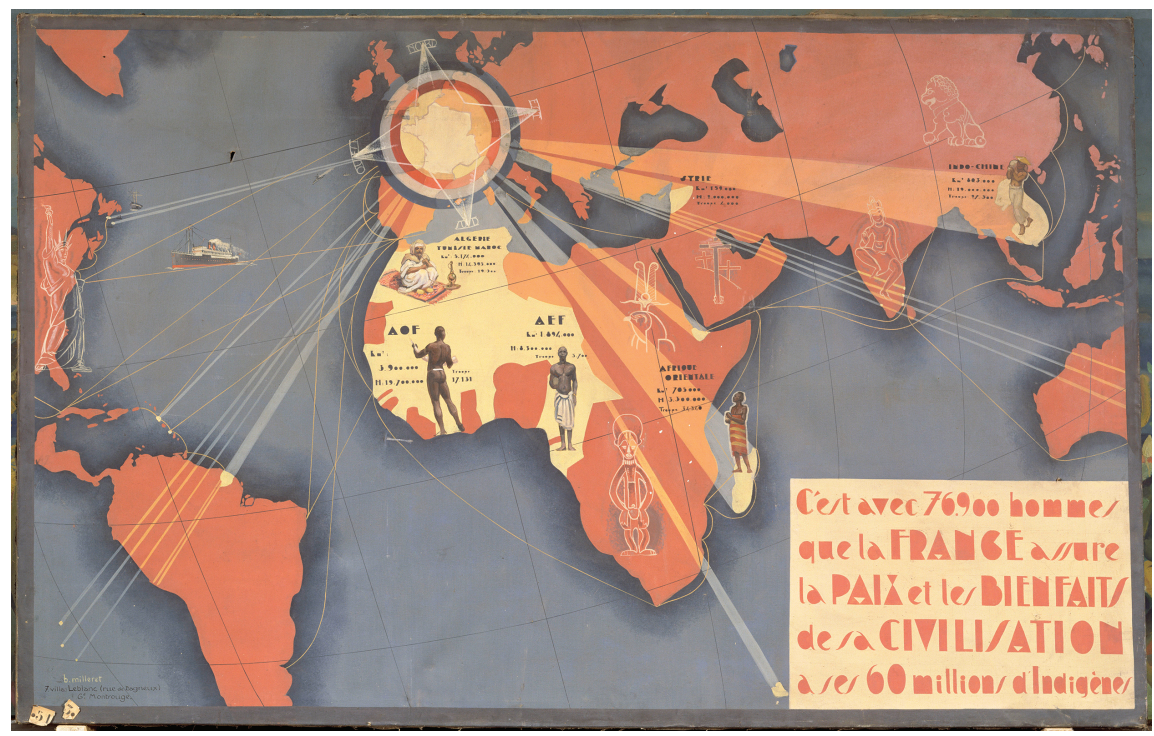

Figure 1: Map by B.Milleret, exhibited at the Exposition coloniale in Paris, 1931. Photo (C) RMNGrand Palais (musée du quai Branly - Jacques Chirac) / Hervé Lewandowski.

iconography of the mission civilicatrice by illustrating how the Hexagon as the "centre" of civilisation enlightens its colonial "peripheries" and beyond. But the idea of a civilizing mission - in the French as well as in other colonial empires - should not be dismissed as a mere ideological superstructure. As the legitimizing ideology of colonialism it was a genuine element of French colonialism and therefore closely related to ideas and practices of power and sovereignty. ${ }^{3}$ One of the pillars of the French civilizing mission was the spread of the French language. In this sense, to mention only one prominent example, Jules Ferry in a statement in the French Senate in 1891 maintained that

la conquête morale, la civilisation progressive de l'indigène, peut prendre une autre forme. On attire à soi le peuple vaincu, non seulement en respectant sa religion, son statut personnel, ses droits de propriété, mais on l'attire surtout en lui ouvrant des écoles, en le mettant en possession de la langue française, seul véhicule des idées françaises parmi ces populations que nous donnons pour tâche d'élever jusqu'à nous. ${ }^{4}$

3 Alice L. Conklin, A Mission to Civilize: The Republican Idea of Empire in France and West Africa, 1895-1930, Stanford, Ca. 1997; Boris Barth/Jürgen Osterhammel (ed.), Zivilisierungsmissionen: Imperiale Weltverbesserung seit dem 18. Jahrhundert, Konstanz 2005.

4 Jules Ferry, 'Discours sur la question algérienne au Sénat (6 mars 1891)', in: Discours et opinions de Jules Ferry, publiés avec commentaires et notes, par Paul Robiquet, tome septième: 
The citation shows that language and linguistic politics were not only crucial for the French idea of the mission civilisatrice but also for the conception of "cultural sovereignty”. The promotion of civilisation and language as well as a certain idea of power, political rule and sovereignty were not stable but flexible quantities that were closely related to dreams of growth and expansion as well as to fears of loss and decline.

The main purpose of this article is to show how a certain conception of Francophonie developed since the last third of the $19^{\text {th }}$ century, how it shaped French imperial politics and in which ways it was related to ideas and practices of cultural sovereignty. Different to usual assumptions Francophonie and language politics did not only come into being when they were invented as an institutionalized area of policy by President de Gaulle and others against the backdrop of decolonization since the 1960s. Instead what one may call a "Francophonie républicaine" has been developed since the end of the $19^{\text {th }}$ century and was a common endeavour of different actors in politics and state administration, in universities and in the scholarly field as well as in a nascent and growing "civil society". The related ideas and practices of this francophone project aimed towards the inside as well as the outside of the Hexagon, shaped national as well as imperial politics and referred to diplomacy and international politics. ${ }^{5}$ Despite these different but interconnected levels of action, Francophonie as well as the closely related notion of cultural sovereignty are firmly linked to the idea of the "nation-state". Far from being neither a stable nor an absolute category itself, the latter remains a central reference as well as a crucial actor of "sovereignty". With this in mind, the francophone project concerned different, but interconnected notions of "cultural sovereignty": First, it meant the capacity to exercise sovereignty on cultural and educational policy in a strict sense. Second, it defined the project to obtain, defend and expand sovereignty by the means of culture, especially by the expansion of the French language. In this sense, language policy closely linked to a certain conception of cultural sovereignty, reaches far beyond a

Discours sur la politique intérieure (2è partie, depuis le 30 mars 1885), Paris 1898, 197-214, here: 207. Transl.: "the moral conquest, the progressive civilization of the indigenous, can take another form. We attract the defeated people to ourselves, not only by respecting their religion, their personal status, their property rights, but we attract them above all by opening schools to them, by putting them in possession of the French language, the only vehicle for French ideas among these populations that we give the task of raising up to us."

5 See my habilitation thesis, Silke Mende, Ordnung durch Sprache: Francophonie zwischen Nationalstaat, Imperium und internationaler Politik, 1860-1960, Berlin et al. 2020. This article largely relies on the findings of the book. 
narrow conception of culture and constitutes an important aspect of a culturally broadened history of the political. ${ }^{6}$

In a first step, I will therefore analyse the relationship between language, nationstate and cultural sovereignty that was central to the formation of the Francophonie républicaine since the end of the $19^{\text {th }}$ century. In a second step, the perspective will be widened to the French colonial Empire, asking for transfers and entanglements. Especially those nation-states that were at the same time imperial powers were often seeking to translate their conceptions and practices of sovereignty to their empires even though they did this frequently in a modified way. This was also the case for francophone language policy which was characterized by manifold contradictions and fault lines. Finally, in a third step, conflicting conceptions of cultural sovereignty move into the centre and special attention is given to indigenous and (post-)imperial appropriations of the francophone project.

\section{Language, nation-state and cultural sovereignty in the "age of territoriality": The birth of the "Francophonie républicaine"}

Cultural sovereignty is a relational concept that is not a fixed or stable category but more a movable frame that could be filled in many different ways. Despite its flexibility it is closely related to the exclusive claims of the nation-state, both in its intentions to homogenize populations and societies and in expanding its influence in- and outside its own territory. The context for this was the "age of territoriality": According to Charles Maier it began in the midst of the $19^{\text {th }}$ century and endured until the last third of the $20^{\text {th }}$ century. For a certain imaginary of territoriality the formation and further development of modern statehood was crucial. Much more than in early modern times and significantly based on statistical knowledge, statehood now was increasingly seeking to explore, control and grasp its own territory in order to form a common "decision space” as well as a shared "identity space". ${ }^{7}$ For the rising ambitions of nation-states language and

\footnotetext{
6 See Gregor Feindt/Bernhard Gissibl/Johannes Paulmann (eds.), Kulturelle Souveränität: Politische Deutungs- und Handlungsmacht jenseits des Staates im 20. Jahrhundert, Göttingen 2017, 9-46.

7 Charles S. Maier, 'Consigning the Twentieth Century to History: Alternative Narratives for the Modern Era', in: AHR 105 (2000), 3, 807-831; Charles S. Maier, Once Within Borders: Territories of Power, Wealth, and Belonging Since 1500, Cambridge, Mass./London 2016.
} 
language policy became important elements. As is well-known, modern historical research on nationalism in the tradition of Benedict Anderson has already emphasized the importance of a uniform language for the construction and maintenance of an 'intact' national identity. ${ }^{8}$ Others like the historian Eugen Weber, himself deeply shaped by modernization theories, have underlined the instrumental character of language and education for the development and "modernization" of rural France since the last third of the $19^{\text {th }}$ century. ${ }^{9}$ In this view language becomes a form of "soft infrastructure" comparable to railroads and telegraphs that helped the state in capturing, exploring and governing the country. The prominent school reforms in the 1880s initiated and carried out by Jules Ferry went in this direction. In a vigorously secular spirit they did not only fight the catholic influence on education but they also sought to push back dialects and regional languages that were still widespread in a number of French regions. ${ }^{10}$ In this sense the Third Republic pursued a partly radical language policy in order to implement visions of cultural sovereignty in the supposed "peripheries" of the country that were not only depicted as geographically remote and socioeconomically backward but also as culturally retarded. In this sense the republican Léon Gambetta had proclaimed already in 1871:

Les paysans sont intellectuellement en arrière de quelques siècles sur la partie éclairée du pays. Oui, la distance est énorme, entre eux et nous qui avons reçu l'éducation classique et scientifique, même imparfaite, de nos jours; qui avons appris à lire dans notre histoire; nous qui parlons notre langue, tandis que, chose cruelle à dire, tant de nos compatriotes ne font encore que la balbutier. ${ }^{11}$

8 Benedict Anderson, Imagined Communities: Reflections on the Origin and Spread of Nationalism, London/New York 1983.

9 Eugen Weber, Peasants into Frenchmen: The Modernization of Rural France 1870-1914, Stanford, Ca. 1976.

10 Cf. for a very differentiated perspective on this topic: Jean-François Chanet, L'école républicaine et les petites patries, [Paris] 1996.

11 Léon Gambetta, 'Discours prononcés le 19 février 1871 à l'Assemblée nationale (proposition de M. Jules Favre, tendant à la nomination d'une commission pour assister M. Thiers dans les négociations), et le 26 juin 1871, à la réunion des délégués des comités républicains de la Gironde, à Bordeaux', in: Discours et plaidoyers politiques de M. Gambetta, publiés par Joseph Reinach, Tome II, 2è partie (19 février 1871-24 juillet 1872), Paris 1881, 1-35, here: 22. Transl.: "The peasants are intellectually back some centuries on the enlightened part of the country. Yes, there is a great distance between them and us, who have received a classical and academic education, however imperfect, that is up-to-date; who have learned to read from our history; who speak our language, while, cruelly enough, so many of our compatriots are still just stammering." 
However, not only politicians and the state were crucial for the genesis of a francophone project since the last third of the $19^{\text {th }}$ century. Various actors in politics and state administration worked hand in hand with the expanding academic field as well as with an emergent "civil society". They formed a dispositive of institutions, discourses and practices that one can name the "Francophonie républicaine". The promotion of the French language went hand in hand with the spread of republican values and a civilizational model that was deeply rooted in the universalistic ideas of $1789 .^{12}$

Even before the 1880s, several disciplines had fostered the association of language, population and territory and therefore potentially provided arguments for language policy. But in the late $19^{\text {th }}$ century the political context changed and made former utopias of linguistic governing more feasible. On the one hand, eager debates about national rivalries and regeneration became louder. On the other, the republican state and the academic field formed a kind of symbiotic relationship that the figure of the "republican intellectual" (Christophe Charle) embodied. ${ }^{13}$ The financial and personal expansion of universities and academic research encouraged the differentiation and the foundation of new disciplines, linguistics among others. ${ }^{14}$ Not only the latter helped to structure and prefigure discourses on language and influenced reflections on Francophonie. Particularly those branches of linguistics that continued to work and argue in a historical and geographical perspective supported national discourses that imagined the French nation as a linguistic community despite Ernest Renan's famous rejection of this idea in 1882. However, knowledge generated by linguists helped to objectivate ideas of a national territory that should be integrated by the spread of French as a common language. In this sense Ferdinand Brunot, the author of a monumental history of the French language, argued in 1905: „Si, en effet, l'unité de langue n'est pas, comme on l'a dit quelquefois, le lien même qui fait la patrie, du moins elle resserre ce lien au point de le rendre presque indissoluble. “15

12 For the visions and attempts of language policy by the Revolutionaries of 1789 see: Michel de Certeau/Dominique Julia/Jacques Revel, Une politique de la langue: La Révolution française et les patois. L'enquête de Grégoire, Paris 1975; Alyssa Goldstein Sepinwall, The Abbé Grégoire and the French Revolution: The making of modern universalism, Berkeley 2005.

13 Christophe Charle, La république des universitaires, 1874-1940, Paris 1994; Christophe Charle, Naissance des „intellectuels“, 1880-1900, Paris 1990.

14 Giulio Lepschy (ed.), History of Linguistics. Vol. IV: Nineteenth-Century Linguistics, London/New York 1992; Sylvain Auroux (ed.), Histoire des idées linguistiques. Vol. 3: L’hégémonie du comparatisme, Liège 2000.

15 Ferdinand Brunot, La réforme de l'orthographe: Lettre ouverte à M. le Ministre de l'Instruction Publique, Paris 1905, 15. Transl.: "If, indeed, the unity of language is not, as has sometimes 
As a kind of paradigmatic "republican intellectual" Brunot not only embodied the close alliance between academic scholarship and the state but also the relationship to a third important actor in the nascent francophone project, namely the growing “civil society". A huge number of new associations and scholarly societies arose with educated citizens as their major clientele who often originated from the academic or liberal professions. ${ }^{16}$ Beyond their engagement for the promotion of the French language, they were characterized by many commonalities. Besides their social background in the academic Parisian middle class, they widely shared political attitudes that grounded in the values of the Third Republic and referred to the "great revolution". From the ideas of 1789 they deduced a conception of Francophonie that considered the French language as an outstanding medium that incarnated the ideas of the Enlightenment as well as rationality and absolute modernity. According to the universalistic mission of the revolutionaries language promotion went hand in hand with the propagation of a civilizational model. It did not only aim at all groups and classes inside the Hexagon but also outside France, both in its colonies and in foreign countries.

Three closely interrelated associations became crucial to the "Francophonie républicaine": That was, firstly, the Alliance Française (AF). ${ }^{17}$ Founded in 1883 it comprised not only fervent republicans but a large coalition of supporters from different political camps. Although its goal was (and remains) the promotion of the French language outside France its leaders also recognized its integrative character inside the country. Thus in 1888 its general secretary, Pierre Foncin, came to talk about the huge divergences that shaped France and its political landscape "between North and South, West, East and the Centre". He argued that language was an important element of cohesion able to overcome all rivalries and conflicts: „La langue française est l'expression de toutes les consciences, elle plane au-dessus de toutes rivalités et de toutes les batailles. La propagation pure et simple de la langue française est un programme que tout le monde peut admettre et signer." 18

been said, the very bond that makes the homeland, at least it tightens this bond to the point of making it almost indissoluble."

16 Pierre Singaravélou, 'Aux origines coloniales de la francophonie. Le rôle pionnier des associations et des sociétés savantes', in: Sylvie Guillaume/Noble Akam (eds.), Les associations dans la francophonie, Pessac 2006, 63-74.

17 François Chaubet, La politique culturelle française et la diplomatie de la langue: L'Alliance française, 1883-1940, Paris 2006.

18 'Conférence de M. P. Foncin', in: Bulletin de l'Alliance Française 26 (1888), 166-173, here: 171. Transl: "The French language is the expression of all consciences, it hovers above all rivalries and battles. The pure and simple propagation of the French language is a program that everyone can admit and sign." 
Another important actor within this francophone network of associations was, secondly, the Alliance israélite universelle (AIU), a Jewish organization that had been founded already in 1860 in order to fight the discrimination and persecution of Jews, particularly in the declining Empires of Central and Eastern Europe as well as in the Balkans. ${ }^{19}$ A second pillar of its work became the education of Jewish children outside France. For this purpose the AIU established a large network of French-language schools throughout the Mediterranean including North Africa and the Ottoman Empire following a kind of own civilizational mission in order to emancipate Jewish communities in these regions. ${ }^{20}$ Thirdly, in 1902, the Mission laïque française (MLF) was launched with a clearly secular agenda. ${ }^{21}$ In order to compete with religious, mostly catholic missions that were firmly established in the French colonial empire as well as in France's informal zones of influence they founded French schools with a main emphasis, analogues to the AIU, in the Ottoman Empire. Thus the Francophonie républicaine did not only concentrate on the French colonies and 'classical' foreign countries but turned also more to the informal zones of influence envisaged by French imperialism, namely the Bassin Méditerranéen. ${ }^{22}$

In the "age of territoriality" language and language policy thus became a serious element of political assertiveness and a significant symbol of state sovereignty in- and outside France. As seen it was a political program that aimed at the cohesion of the nation-state and the control of its territory. But at the same time its promoters expanded their horizons beyond the Hexagon. Thus in a second step the French colonial Empire becomes the centre of interest. Which ideas and practices of Francophonie shaped French imperial politics? What were the transfers and entanglements between the empire and its metropole? And how was this related to the concept of cultural sovereignty?

19 André Kaspi (ed.), Histoire de l'Alliance israélite universelle de 1860 à nos jours, Paris 2010. 20 See Aron Rodrigue, French Jews, Turkish Jews: The Alliance israélite universelle and the politics of Jewish schooling in Turkey, 1860-1925, Bloomington 1990.

21 Éléments pour une histoire de la Mission Laïque Française, 1902-1982 (Numéro spécial de "Dialogues. Bulletin de liaison des professeurs français à l'étranger"), [Paris 1982].

22 See Patrick Cabanel (ed.), Une France en Méditerranée: Écoles, langue et culture françaises, XIXè-XXè siècles, Grâne 2006. 


\section{Francophonie "en flagrant délit": French language policy and cultural sovereignty in the French Empire}

The rising of national aspirations and rivalries as well as the second imperial expansion since the 1880s were closely related to the idea of the mission civilisatrice. Already in 1885 the notorious Jules Ferry, not only one of the architects of the Third Republic's educational reforms but also a fervent promoter of its imperial expansion, had highlighted the importance of the French language as a geopolitical factor. France, he argued, could not content itself with a similar role as smaller nations like Belgium or Switzerland. For the "grandeur de la France" the French language was an outstanding asset. According to Ferry, the republican party had shown that France "ne peut pas être seulement un pays libre, qu'elle doit aussi être un grand pays, exerçant sur les destinées de l'Europe toute l'influence qui lui appartient, qu'elle doit répandre cette influence sur le monde et porter partout où elle le peut sa langue, ses mœurs, son drapeau, ses armes, son génie.”23

The metropolitan discourse inspired especially the discourses concerning Francophonie and language policy at large. At least in theory an empire-wide promotion of the French language should allow the progressive rapprochement of indigenous people to French "civilization". Conversely this meant that indigenous languages and its speakers were devalued and oppressed. ${ }^{24}$ In his instructions published in 1903 that also summarized French educational policy in Madagascar since the official integration of the country into the French colonial empire in 1896 Governor Galliéni insisted that teaching in all schools had to be organized "in a resolutely French sense". On the one hand he reminded that:

l'extension donnée à l'usage de notre langue était l'un des plus puissants moyens dont nous disposions pour assimiler nos nouveaux sujets, les initier à nos idées et à nos coutumes et enfin, les préparer à fournir le concours nécessaire aux entreprises de nos colons. ${ }^{25}$

23 Jules Ferry, 'Discours du 28 juillet 1885', in: Discours et opinions de Jules Ferry, publiés avec commentaires et notes par Paul Robiquet, tome cinquième: Discours sur la politique extérieure et coloniale, Paris 1897, 172-220, 220. Transl.: "cannot only be a free country, that it must also be a great country, exercising over Europe's destiny all the influence that belongs to it, that it must spread this influence over the world and carry wherever it can its language, its customs, its flag, its weapons, its genius."

24 See the classical study of Louis-Jean Calvet, Linguistique et colonialisme: Petit traité de glottophagie, Paris 2002 [first edition: 1974].

25 'Instructions', in: Bulletin Officiel de Madagascar et de ses Dépendances, année 1903, Nr. 87, $\mathrm{du} 1^{\mathrm{er}}$ au 30 juin 1903, 548-574, here: S. 551. Transl.: "The extension given to the use of our 
On the other hand he referred to another decree that in 1897 had stipulated that all Malagasies employed by the French government or administration must have skills in French language. ${ }^{26}$ Thus a mere functional and instrumental approach to the promotion of French language went hand in hand with a discourse that preached assimilation and that was more oriented at the ideas of the mission civilisatrice. We have already seen the interaction of both perspectives in the context of nation-building in the metropole, and both were closely interrelated with a certain concept of cultural sovereignty.

As in the metropoles, politics of territoriality shaped colonial empires, the French included. It did not only aim at quantitative expansion but also at the spatial penetration and control of the territory and tried to determine colonial borderlines. ${ }^{27}$ In his rather brief words on the colonial dimension of territorial statehood Charles Maier also refers to the various attempts of empires at establishing spatial control of imperial territories, especially with the help of infrastructural projects. ${ }^{28}$ Although, at first sight, these attempts were quite similar to the ideas and practices of territorial governing in the metropole it is necessary to underline the significant differences. Despite local dissimilarities within the empire, the French colonial administration on the whole was far away from the professionality and efficiency of administrative structures and practices in the metropole. With regard to the needs of administration and governing, however, some functions attributed to education and language politics in the empire were quite similar to those in the Hexagon.

From a mere instrumental and administrative perspective that was especially interested in smoothly running processes it was only a basic knowledge in French that was considered as necessary. As a consequence the curricula were largely arranged according to the needs of the local colonial administration. Particularly in state-run schools the majority of the graduates were only certified with special diplomas that were not the same as in the metropole. Only a small indigenous elite had the chance to enjoy higher education with equivalent French degrees. As a consequence the vast majority of indigenous people were only familiarized

language was one of the most powerful means at our disposal to assimilate our new subjects, to introduce them to our ideas and customs, and finally to prepare them to provide the necessary assistance to the enterprises of our settlers."

26 Ibid., 552.

27 See Hélène Blais, 'Reconfigurations territoriales et histoires urbaines. L'emprise spatiale des sociétés coloniales', in: Pierre Singaravélou (ed.), Les empires coloniaux, XIXè-XXè siècle, Paris 2013, 169-214; Hélène Blais/Florence Deprest/Pierre Singaravélou (eds.), Territoires impériaux: Une histoire spatiale du fait colonial, Paris 2011.

28 Maier, Once Within Borders, especially chapter 5. For the German example see: Dirk van Laak, Imperiale Infrastruktur: Deutsche Planungen für eine Erschließung Afrikas, 1880-1960, Paderborn et al. 2004. 
with basic skills in reading and writing. Altogether, this aimed principally at the formation of workers and administrative staff in the lower ranks. ${ }^{29}$

The instrumental and functional considerations that shaped the sector of education in general as well as the promotion of the French language in particular may be illustrated, with all the cynicism that went with it, by the following episode in Annam-Tonkin. After the end of the Sino-French war Paul Bert was appointed general resident of Madagascar in 1886 in order to "pacify" the new French protectorates. He quickly began to establish schools for which he, however, provided only a modest budget and few professional teachers. For Bert, the promotion of the French language served purely instrumental needs:

Il n'était pas nécessaire qu'un jeune garçon indigène pût dire à nos officiers: ,voulez-vous me permettre de vous accompagner, $\mathrm{j}$ 'ai appris un peu le français, je pourrais vous servir d'interprète et je tiendrais votre cheval'. Il suffit qu'il dise: ,moi aller avec vous, parler français, tenir cheval‘.$^{30}$

It was the same Paul Bert, as a close political companion of Jules Ferry, that had vigorously campaigned for republican school politics and educational reform in the metropole. His statement therefore underlines again the huge gap that divided imperial from metropolitan practices of Francophonie. To name only a few examples, at the end of the $19^{\text {th }}$ century elementary schools in French West Africa counted altogether only 2,500 pupils. The numbers in French Equatorial Africa were similarly low. Especially in sub-Saharan Africa the number of schools remained very small, and this only should change after the Second World War. ${ }^{31}$ In Algeria that was an integral part of France and therefore a special case of French colonialism the quota of scolarisation in 1890 amounted to only 1.9 per cent, in 1930 it had only increased to 6 per cent. $^{32}$

29 With examples from different colonies: Dalila Morsly, L'enseignement du français en colonies: Expériences inaugurales dans l'enseignement primaire, Paris 2010. See also Antoine Léon, Colonisation, enseignement et éducation, Paris 1991; Robert Aldrich, Greater France: A history of French overseas expansion, Basingstoke 1996, $224 \mathrm{f}$.

30 Stéphane Kotovtchikhine, Paul Bert et l'instruction publique, Dijon 2000, 110-119, here: 114. Transl.: "There was no need for a young native boy to tell our officers: "Would you allow me to accompany you, I've learned some French, I could interpret for you and I'll hold your horse. All he has to do is say: "Me go with you, speak French, hold your horse."

31 The numbers in: Aldrich, Greater France, 225. For West Africa see also Conklin, A Mission to Civilize, 73-86, and the classical study of Denise Bouche, L'enseignement dans les territoires français de l'Afrique Occidentale de 1817 à 1920: Mission civilisatrice ou formation d'une élite? 2 Vol., Lille 1975.

32 The numbers in: Claude Liauzu, 'L'école du colonisé. Une immense faim scolaire non satisfaite', in: Claude Liauzu (ed.), Dictionnaire de la colonisation française, 2007, 260-264, here: 262. For Algeria see: Fanny Colonna, Instituteurs algériens, 1883-1939, Paris 1975. 
Although we need to underline the varieties within the French empire, we may conclude: Despite official discourses that praised assimilation French imperial educational policy as a whole fell far short of the grandiose promises made in the name of mission civilisatrice. As is well known such striking contradictions did not only characterize education and language promotion but nearly all fields of colonial rule. As Sylvie Thénault has noted with regard to the French colonial state: "la IIIè République française est ainsi prise en flagrant délit de contradiction avec ses propres principes“. ${ }^{33}$ But how things were developing after the long turn of the century and especially after the First World War? And what were indigenous reactions to the francophone project?

\section{Conflicting "cultural sovereignties" and (post-)imperial appropriations}

In the wake of the "Great War“ the second French colonial empire grew larger than ever before thanks to the League of Nations mandates in sub-Saharan Africa as well as in Syria and Lebanon. The latter were former zones of influence where French language policy could tie up to an already dense francophone network formed by long-time established catholic missionaries as well as by the actors of the Francophonie républicaine that had entered the imperial stage since the late $19^{\text {th }}$ century, namely the Alliance israélite universelle and the Mission laïque française. Thus, since the turn of the century "deux France”, a catholic and a republican one, had coexisted and often bitterly concurred in the Mediterranean and in other areas of the French colonial empire in order to proselytize local populations. ${ }^{34}$ The following will not focus on these inner-French conflicts about cultural sovereignty but it will draw attention to indigenous perspectives and appropriations of the francophone project. The French mandate Syria-Lebanon in the interwar-years will serve here as an example. ${ }^{35}$

33 Thénault, L'État colonial, 244. Transl.: "the Third French Republic is thus caught in flagrante delicto of contradiction with its own principles."

34 See J. P. Daughton, An Empire Divided: Religion, Republicanism, and the Making of French Colonialism, 1880-1914, Oxford 2008; Owen White/J.P. Daughton (eds.), In God's Empire: French Missionaries and the Modern World, New York 2012. With special regard to Syria and Lebanon: Julia Hauser/Christine B. Lindner/Esther Möller (eds.), Entangled Education: Foreign and Local Schools in Ottoman Syria and Mandate Lebanon (19-20th centuries), Würzburg 2016.

35 See Jennifer M. Dueck, The Claims of Culture at Empire's End: Syria and Lebanon under French Rule, Oxford/New York 2010; Esther Möller, Orte der Zivilisierungsmission: Französische Schulen im Libanon 1909-1943, Göttingen 2013. 
In its newly acquired mandate, French rule immediately was called into question by anticolonial movements of emancipation. During the Paris Peace conference, they had tried in vain to prevent mandatory rule. ${ }^{36}$ However, for the Syrian opposition, particularly the pro-Arab "National Bloc", the French language often played an ambivalent role. For a long time some propagandists of colonization had feared too intensive dealing with francophone authors and particularly with the pioneers of the Enlightenment because this might furnish critiques of colonialism and engender movements for national independence. Indeed such anticipations should partly become true although the role that language played for this was as diverse as the wide range of emancipation movements. One example was an essay entitled "Bilan d'une equivoque”, written in French by a prominent protagonist of the Syrian National Block in 1939. The author, Jamîl Mardam Bey, could look back on an almost paradigmatic biography for anticolonial leaders. He had passed a part of his education at the École libre des sciences politiques in Paris where, on the eve of the First World War, he and other fellow students formed a pro-Arab network. After the war, he participated as an observer at the Paris Peace Conference. Above all his essay was a sharp critique of the French mandate in Syria. Nevertheless, its author expressed his appreciation of the French language and culture: "La langue française n'a pas été pour les Syriens de l'intérieur un moyen de gagner leur vie ou d'avancer en grade, mais une sorte de fenêtre ouverte sur l'Occident."37

Like Mardam Bey many members of the Syrian elites were not only francophone but in an abstract cultural sense also quite francophile. They referred to European and Western ideas and principles all the more when they were openminded about liberal ideas. Towards the idea of mission civilisatrice and its inherent francophone project this entailed another ambivalence that did not only concern the protagonists of the anti-mandatory opposition but also other actors, like teachers for example that were employed at French schools. Their dilemma has best been described by Esther Möller who points out that they "were teaching a literature that was based on the principles of self-determination but they

36 See Philip S. Khoury, Syria and the French Mandate: The Politics of Arab Nationalism, 1920-1945, London 1987; Daniel Neep, Occupying Syria under the French mandate: Insurgency, Space and State formation, Cambridge 2012.

37 Quoted from: Salma Mardam Bey, La Syrie et la France: Bilan d'une équivoque (1939-1945), Paris 1994, 13-35, here: 9. See also: Doc. 32: '„Le bilan d'une équivoque“: le mandat français jugé par un nationaliste syrien (1939)', in: Anne-Laure Dupont/Catherine Mayeur-Jaouen/Chantal Verdeil (eds.), Le Moyen-Orient par les textes, 19è-20è siècles, Paris 2011, 112-115. Transl.: "The French language was not a means of earning a living or advancing in rank for the Syrians inside, but a sort of window open to the West." 
were part of a quasi-colonial regime that forbid self-determination for the Lebanese and the Syrians. It was this literature that also served to Arab nationalists as inspiration for their uprising against the French rulers." 38

Another important strategy of emancipation movements was the appropriation of some elements of the francophone discourse to justify their own national aspirations. A complaint submitted to the League of Nations in 1935 illustrates this. It originated from the surroundings of the pro-Arab "National Bloc" and was jointly signed by a lawyer and a farmer. The text went through different European concepts of nation-building and discussed the importance of a common language and culture. For many centuries, it argued, the vast majority of Syrians shared the same language, the same culture, the same habits and customs. And even more: "Bien des nations, et la France elle-même avec ses Alsaciens, ses Auvergnats, ses Basques, ses Bretons, ses Corses et ses Provençaux qui tous ont encore leur entité raciale et linguistique, pourraient envier à la Syrie ses éléments d'unité humaine.”39

Supporters of the national movements often used this argument, which was borrowed from European conceptions of nations, in a strategic way. However, certain aspects regarding the link between language and "civilisation" structured also the case made by those who sought to strengthen the use of the Arab language in school or in everyday life. For example, French-directed schools like those run by the MLF or the AIU provided teaching in the Arab language. With the advent of the mandate, the necessity to master the national language became even more urgent. The personnel on the ground was much more sensible to these needs than the central administrations of the MLF or the AIU in Paris. Quite typical was the following view expressed by a director from Aleppo. In his letter to the president of the Alliance israélite universelle he wrote:

Vous savez que depuis que je suis à la tête de vos écoles d'Alep, j’ai pris à cœur le développement de l'enseignement de la langue arabe, la langue nationale des Syriens, qui leur est si nécessaire pour les transactions commerciales et pour leurs relations journalières tant entre eux qu'avec les autorités locales. ${ }^{40}$

38 Möller, Orte der Zivilisierungsmission, 196.

39 Pétition: Abdulkader Sarmini et Djemil Ibrahim Pacha, Alep, le 15 juin 1935, p. 3 (Achives Diplomatiques, La Courneuve: SDN, Côte: 242Q0, N 597). Transl.: "Many nations, and France itself with its Alsatians, Auvergnats, Basques, Bretons, Corsicans and Provençals, all of whom still have their racial and linguistic entity, could envy Syria its elements of human unity.”

40 M. Penso à Monsieur le Président de l'Alliance Israélite Paris, Alep, le 5 juin 1931, 2 (Archives de l'Alliance israélite universelle (AIU): Syrie VII E 063 f). Transl.: "You know that since I have been at the head of your schools in Aleppo, I have taken to heart the development of the teaching of the Arabic language, the national language of the Syrians, which is so necessary to them for 
In the course of the mandate, beyond such pragmatic reasons, political considerations came more and more to the fore, all the more since the perspective of Syrian and Lebanese independence were negotiated since the mid of the 1930s. Particularly meaningful for this view was an appeal that A. Rahmani, AIU-director in Sidon, sent to the Rue La Bruyère in Paris, the headquarters of the AIU, in 1937. On nearly 20 pages, he required an equal status for the Arab language in comparison to French. ${ }^{41}$ According to him the changing political and cultural atmosphere had to result in a "new cultural formula for our schools in the Orient." 42 Implicitly he blamed his superiors in Paris not only to neglect Arab in its curricula but to nourish fundamental distrust towards it. This, he argued, ran the risk that young Jewish Syrians might become strangers in their own land:

Ce qui est plus significatif, c'est le sentiment même de nos élèves en ce qui concerne la langue arabe. Ils témoignent peu d'intérêt à son égard, et l'apprendre est pour eux presque une corvée. [. . .] Que nous le voulions ou non, nous entretenons parmi nos élèves le mépris de leur langue maternelle, de leur langue nationale! ${ }^{43}$

The idea of contesting "cultural sovereignties" also shows in his argument: „Dans la mesure où nous avons réussi à enseigner le français, nous avons détourné la jeunesse de la culture arabe. Systématiquement. Ce fait est inacceptable, incroyable." ${ }^{44}$ In the same way as we saw before with Mardam Bey or the complaint to the League of Nations, he reversed the idea of the French civilizing mission and its inherent francophone project:

Nous sommes Orientaux, et je dirai sans crainte du ridicule, que notre mission historique est de cultiver et d'approfondir la langue et la civilisation arabes; de les comprendre, de les aimer, de montrer à l'europe [sic!] les caractères propres de leur génie, de dégager clairement leur originalité, de mettre en lumière leur apport à la civilisation. En d'autres termes, fidèles à notre mission séculaire, nous devrions servir d'intermédiaire, de trait d'union entre l'Orient et l'Occident. ${ }^{45}$

commercial transactions and for their daily relations both among themselves and with the local authorities."

41 Le directeur de l’École de Saida au Président de l'AIU, Saida, le 26 décembre 1937 (Archives de l'AIU: Liban XIII E 118).

42 Ibid., 1.

43 Ibid., 4f. Transl.: "What is more significant is the very feeling of our students regarding the Arabic language. They show little interest in it, and learning it is almost a drudgery for them. [. . .] Whether we like it or not, we maintain among our students contempt for their mother tongue, their national language!"

44 Ibid, 9 Transl.: "To the extent that we have succeeded in teaching French, we have diverted youth from the Arab culture. Systematically. This fact is unacceptable, unbelievable."

45 Ibid., 9f. Transl.: "We are Orientals, and I will say, without fear of ridicule, that our historical mission is to cultivate and deepen the Arab language and civilization; to understand them, 
With regard to the Francophonie in its imperial context and contesting "cultural sovereignties" the harsh critique of Rahmani illustrates how claims of Arab culture and language in different milieus of the Syrian society were vehemently rising and entered more and more into competition with the francophone project. However, the French language and culture remained an important cultural point of reference - albeit often in quite another way than originally intended by the Francophonie républicaine.

\section{Conclusion}

What has been exemplary shown for Syria and the Lebanon under French mandate became even more vigorously after the Second World War and in the whole French colonial Empire: The question of emancipation and national independence as well as the issue of an enduring influence of the French "civilization" and language were nearly everywhere on the agenda. French reactions to these challenges were also situated in the fields of education and language policy. Only now, a stronger effort for schooling and alphabetization was seriously undertaken, particularly in the African colonies. After decolonization, it was the institutionalized Francophonie "invented" by Charles de Gaulle and others that was meant to maintain French influence over its former colonies. One of the many long lasting consequences of this policy was a persistent ambivalence towards French culture, language and "civilization" that shaped the post-colonial societies of the former French empire. In order to illustrate this only briefly the well-known Congolese author Emmanuel Dongala should be cited. In his Les petits garçons naissent aussi des étoiles published in 1998 he got to the heart of the paradox that had always been inherent to the project of Francophonie républicaine:

Ils nous commandaient, ils dirigeaient le pays, l'exploitaient, nous ont appris leur langue, nous ont envoyés dans leurs écoles et nous ont donné comme nouveaux ancêtres les Gaulois. C'est pourquoi nous parlons encore français aujourd'hui, adorons la bouffe française et nous aimons toujours aller passer nos vacances en France même si aujourd'hui il est plus facile d'avoir un visa pour aller sur la Lune que d'en avoir un pour aller dans ce pays. ${ }^{46}$

\footnotetext{
to love them, to show europe [sic!] the characteristics of their genius, to clearly identify their originality, to highlight their contribution to civilization. In other words, faithful to our age-old mission, we should serve as an intermediary, as a link between Orient and Occident."

46 Emmanuel B. Dongala, Les petits garçons naissent aussi des étoiles, Paris 1998, 14. Transl.: "They commanded us, ran the country, exploited it, taught us their language, sent us to their schools and gave us the Gauls as our new ancestors. That's why we still speak French today,
} 
At the same time after the Second World War, not only in the empire but also in the metropole the imaginary of cultural sovereignty closely linked to the francophone project became more and more fragile. While decolonization required a reformulation of Francophonie outside the Hexagon, dialects and regional languages regained ground inside it. On the one hand this became visible on the politicalinstitutional level with the "loi Deixonne" in 1951 that readjusted the teaching of regional languages in French schools. Even if it concerned only some of them and their use in class was only facultative, for the first time the French republic officially recognized their right to existence. On the other hand the regional question and with it the cause of regional languages became increasingly important in intellectual debates and French society, especially since the 1960s. Once again scholarly engagement and civil society went hand in hand. One of the most prominent examples is the French linguist Robert Lafont, a well-known expert of Occitan and fervent advocate for the cause of regionalism. In the 1960s and 1970s in his political writings he put the case of a "regionalist revolution" and required the "decolonization of France". ${ }^{47}$ As he denounced French regional politics as "internal colonialism", he had to face harsh criticism, also by other intellectuals like the writer and left-wing intellectual Jean-Marie Domenach. ${ }^{48}$

This concluding episode underlines again the challenges and pitfalls of treating questions of language policy and Francophonie as well as associated notions of cultural sovereignty in the French metropole and its former empire in the same analytical field - a task that requires sensibility and differentiation but nonetheless bears the potential to better understand notions of cultural sovereignty and self-conceptions of political entities that were at the same time "nations-states" and "empires". 49

we still love French food and we still like to go on holiday to France even though today it is easier to get a visa to go to the moon than to go to this country."

47 Robert Lafont, La révolution régionaliste, Paris 1967; Robert Lafont, Décoloniser en France: Les régions face à l'Europe, Paris 1971.

48 This finds expression in the issue "unité nationale et minorités culturelles" of the journal "Esprit" in December 1968 with contributions among others by Jean-Marie Domenach and Robert Lafont. See Esprit 12 (1968).

49 See Jörn Leonhard/Ulrike von Hirschhausen, Empires und Nationalstaaten im 19. Jahrhundert, Göttingen 2009. 